\title{
Mechanical Damages and Chemical Treatments in the Quality of Maize Seeds Stored
}

\author{
Bárbara Gomes Ribeiro ${ }^{1}$, Raquel Maria de Oliveira Pires ${ }^{1}$, Tatiana Botelho Fantazzini ${ }^{1}$, \\ Hesoisa Oliveira dos Santos ${ }^{1}$, Dayliane Bernardes de Andrade $^{1}$ \& Renato Mendes Guimarães ${ }^{1}$ \\ ${ }^{1}$ Agriculture Departament, Universidade Federal de Lavras, Lavras, MG, Brazil \\ Correspondence: Raquel Maria de Oliveira Pires, Universidade Federal de Lavras, Campus Univsersitario, s/n, \\ Aquenta Sol, Lavras, MG, 37200-000, Brazil. Tel: 55-035-3829-1319. E-mail: raquel.mopires@gmail.com
}

Received: November 20, 2018

Accepted: December 20, 2018 Online Published: February 15, 2019

doi:10.5539/jas.v11n3p482

URL: https://doi.org/10.5539/jas.v11n3p482

\begin{abstract}
The current system of seeds production is highly mechanized and these operations can contribute to losses in quality due the incidence of mechanical damages. The objective in this work was to study the effect of the chemical treatment and the storage on quality of maize seeds with mechanical damages. The seeds used were individually analyzed through X-ray test for the obtainment of three lots; 1-seeds without separation, 2-seeds without mechanical damages and 3-seeds with mechanical damages. The lots were evaluated according the physiological quality, sanity and enzymatic analyzes before and after the chemical treatment with the insecticide Maxim Advanced ${ }^{\circledR}$ and the fungicide Cruiser ${ }^{\circledR}$ and also after 90 days of storage. The chemical treatment of maize seeds is efficient in the control of pathogens, like Fusarium sp. The performance of seeds with internal and external damages can be maintained for 90 days when treated with fungicides and insecticides and stored in environment conditions. The isoenzymatic patterns of catalase (CAT), superoxide dismutase (SOD), malate dehydrogenase (MDH) and alcohol dehydrogenase (ADH), confirmed the higher deterioration of non-treated seeds during the storage. The mechanical damages found in seeds contribute to the reduction of viability and vigor of maize seeds.
\end{abstract}

Keywords: Zea mays L., physiological quality, X-ray test

\section{Introduction}

In the process of maize seeds production, the mechanical damages have been revealed as one of the major problems compromising the physiological quality and sanity of seeds. According Teixeira et al. (2002), during the threshing, processing and sowing, the maize seeds are submitted to impacts causing immediate or latent damages, contributing to the reduction of physiological and physical qualities of lots.

In order to preserve the quality of maize seeds and to contribute with the increase of investment return of culture, there is the necessity of mechanical damages reduction (Marchi et al., 2006). Between the techniques of mechanical damages identification, stands out the X-ray test, a non-destructive test that uses low doses of radiation. Many works were realized using this procedure in order to evaluate the physiological quality of maize seeds analyzing the intern structures as well as the presence of mechanical damages (Cícero \& Banzatto Júnior, 2003; Vaz Mondo \& Cícero, 2005; Gomes Junior \& Cícero, 2012).

Beyond the mechanical damages, many are the factors that influence the conservation of viability and vigor of seeds during the storage, between them, the initial conditions of seeds, climatic conditions during the maturation, conditions of drying, relative air humidity, temperature of storage, action of fungi and insects and also the duration of the storage period.

During the storage, seeds, mainly those which were damaged, stands susceptible to the attack of pathogens and pests and are subject to the deterioration due to the interaction between the physical, chemical and biological aspects, however, these seeds can be stored for long periods of time, without significant losses of quality, since preventive cares are taken (Martin et al., 2007).

The mainly fungi infecting the maize seeds are Fusarium moniliforme and Cephalosporium acremonium in conditions of seeds production field, and Aspergillus sp. and Penicillium sp., in conditions of storage (Smiderle et al., 2003). 
With the purpose to study the relations between the occurrence of mechanical damages, the fungicide treatment and the pathogen incidence, Marchi et al. (2006) verified that there was increase in the incidence of fungi with the increase of damages and the fungi that had higher incidence were Fusarium moniliforme and Cephalosporium sp.

Knowing that the use of healthy seeds is one of the main requirements for the obtainment of good yields, the chemical treatment has becoming indispensable, being used like a protection tool to the seeds, both in the yield as well as in the storage (Juliatti, 2010).

With the exposed, the objective in this study was to evaluate the effect of chemical treatment and the storage on the quality of maize seeds with mechanical damages.

\section{Material and Methods}

The experiment was realized in the Central Laboratory of Seeds Analyzes in de Department of Agriculture at Federal University of Lavras (UFLA).

Were used seeds from a commercial hybrid, susceptible to mechanical damages, produced in Ituiutuba- Minas Gerais, from the crop 2013/2014, recently harvested, sieve 18-M1, provided by the SeedCare Institute.

To compose the three evaluated lots, the recently harvested seeds were individually evaluated according the presence of mechanical damages detected by the X-ray test. The lots were characterized by: Lot 1-seeds recently harvested; Lot 2 -seeds without damages and Lot 3 -seeds with damages identified by the X-ray analyzes.

Following, four replications of 50 seeds of each lot were submitted to different methods of mechanical damages identification to determine the better methodology to be used. Were realized the following procedures: visual evaluation using common loupe stereoscopic, evaluation with analyzer seeds system GroundEye ${ }^{\mathbb{B}}$ using the version S800 and seeds soaked in stainer fast green. For the fast green application, seeds were placed in solution of $0.1 \%$ by two minutes, then were washed in current water to remove the excess of the product.

After, was determined the initial quality of each lot through the following determinations and tests:

Determination of water content: was used the oven method at $105^{\circ} \mathrm{C}$ by 24 hours (MAPA, 2009).

Germination test: was realized according Regras para Análise de Sementes (RAS) being the count of normal seedlings realized at the fourth day (first count of germination) and the seventh day (final count of germination) (MAPA, 2009).

Emergence test: realized in plastic trays with sand and soil $(2: 1)$ and depth of $1.5 \mathrm{~cm}$. In the emergence was evaluated the number of normal seedlings at 100 days after sowing. The emergence speed index (ESI) was calculated according the formula proposed by Maguire (1962), with daily readings until the stabilization of stand.

Cold test: was realized according the methodology described by Dias and Barros (1995), without soil.

Accelerated aging test: developed according the methodology described by Vieira and Krzyzanowski (1999).

Tetrazolium test: seeds were soaked in water by 14 hours and after were cut longitudinally and immersed in solution of 2, 3, 5 triphenyl tetrazolium at $0.5 \%$ for four hours at $30{ }^{\circ} \mathrm{C}$ in the dark. Then, seeds were washed in current water and evaluated according the viability and the presence of damages.

Electric conductivity test: was conducted following the methodology proposed by Brandão Júnior et al. (1997).

Sanity of seeds: was evaluated through the blotter test with freezing, according described by Fantazzini et al. (2016).

Electrophoresis analyzes of enzymes: the enzyme extracts were obtained by the maceration of $20 \mathrm{~g}$ of seeds in presence of polyvinylpolypyrrolidone (pvpp) and liquid nitrogen, and after were stored at temperature of $-86{ }^{\circ} \mathrm{C}$ in deep freezer.

The electrophoretic run was realized in a discontinuous system of polyacrylamide gels at $7.5 \%$ (separating gel) and $4.5 \%$ (concentrating gel). The system gel/electrode used was the Tris-glycine $\mathrm{pH} 8.9$. Were applied in the channel of gel $50 \mu \mathrm{L}$ of the supernatant of sample and the electrophoretic run was realized at $150 \mathrm{~V}$ by 5 hours. At the end, the gels were revealed for the enzymes alcohol dehydrogenase (ADH-EC 1.1.1.1), malate dehydrogenase (MDH-EC 1.1.1.37), superoxide dismutase (SOD-EC.1.15 .1.1.) and catalase (CAT-EC.1.11.1.6) according the methodology proposed by Alfenas (2006).

After, seeds of each lot were divided in two parts, being the first one submitted to the chemical treatment with the fungicide Maxim ${ }^{\circledR}$ Advanced composed by Metalaxyl-M, Thiabendazole and Fludioxonil, and the second 
one submitted to the treatment with insecticide Cruiser ${ }^{\circledR}$ composed by Thiamethoxam. These treatments were industrially realized, applying the doses recommended by the manufacturer. After the chemical treatment, one part of seeds from each lot, was evaluated according the physiological quality, being the other part stored in environment conditions $\left(25^{\circ} \mathrm{C} / 75 \%\right.$ UR) for 90 days. At the end of the storage period, the lots were once again evaluated by the quality.

For the first part of the experiment (lots characterization), the statistical design used was entirely randomized with one factor (lots) and eight replications for each test. For the second part was used the same experimental design in factorial scheme of $3 \times 2 \times 2$, being three lots, seeds treated and non-treated, and two periods of storage with four replications for each test. For the comparison of averages were used the Scott-Knot test at 5\% of probability and the analyzes were realized using the statistical program SISVAR $($ Ferreira, 2011).

\section{Results and Discussion}

In Table 1, are found the results about the evaluation of mechanical damages presence in maize seeds using different techniques. Seeds were initially separated by the x-ray test being later submitted to the others tests to thereby, determine the most efficient methodology to separate the seeds according the damages.

Table 1. Percentage of seeds with damage found by each methodology $(\mathrm{F}=$ Fast Green; $\mathrm{L}=\mathrm{Loupe}$; GE $=$ GroundEye ${ }^{\circledR} ; \mathrm{XR}=\mathrm{X}$-rays)

\begin{tabular}{lllll}
\hline Lots & F & L & GE & XR \\
\hline 1-Original & 24 & 9 & 0 & 53 \\
2-Without damages & 21 & 0 & 0 & 0 \\
3-With damages & 26 & 11 & 0 & 100 \\
\hline
\end{tabular}

The radiographic analysis was more efficient in the identification of seeds with invisible damages to naked eyes (latent damages). The use of loupe, despite of to allow the visualization of cracks, does not allow to visualize the intern damages, cause that, did not show to be efficient when compared to the technique of x-ray. By GroundEye $^{\circledR}$, was not possible to identify differences between seeds from the three lots. With aid of the stainer fast green, was possible to identify $21 \%$ to $26 \%$ of seeds with damage, however, did not show to be efficient by the fact of the identified seeds not necessarily contained damages when correlated to the observations by the $\mathrm{x}$-ray test.

The hybrid used in this study had roughness in the pericarp and the fast green, in some cases, colored this roughness, what led to the erroneous classification of seed with damage (Figure 1).

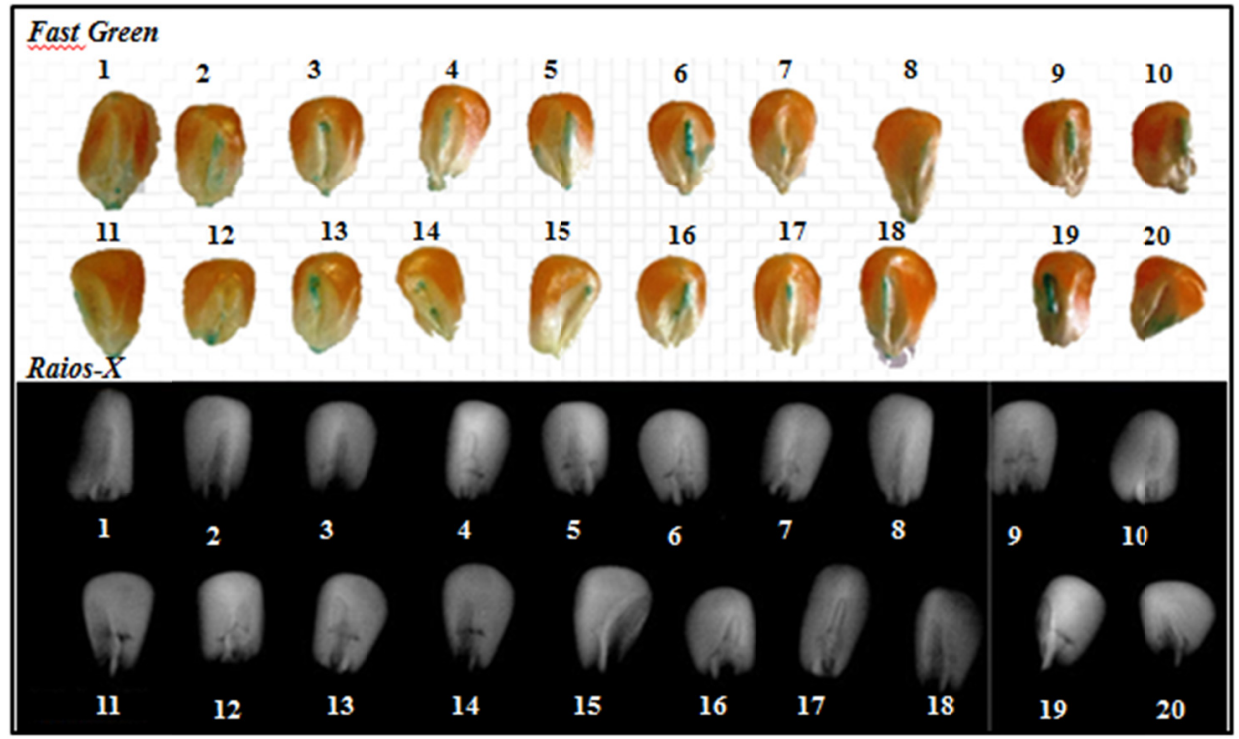

Figure 1. Maize seeds submitted to the stainer fast green and after to the x-ray test to evaluate the mechanical damages 
Was possible to observe by the results of germination test (G), first count of germination (FC), emergence (E) and cold test (CT) that que lot 1 (original) and the lot 2 (without damage) were statistically similar and superior to the lot 3 (with damages). For the accelerated aging test (AA), the results of the lots 1 and 3 were similar and inferior to the lot 2. For the others tests, emergence speed index (ESI) and electric conductivity (EC), there wasn't significant difference between the lots (Table 2).

Table 2. Physiological results of three lots of maize seeds

\begin{tabular}{llllllll}
\hline Lots & G (\%) & FC (\%) & E (\%) & ESI & CT & AA & EC \\
\hline 1-Original & $98 \mathrm{~A}$ & $96 \mathrm{~A}$ & $100 \mathrm{~A}$ & 12.27 & $98 \mathrm{~A}$ & $94 \mathrm{~B}$ & 12.48 \\
2-Without damages & $98 \mathrm{~A}$ & $94 \mathrm{~A}$ & $100 \mathrm{~A}$ & 12.36 & $98 \mathrm{~A}$ & $98 \mathrm{~A}$ & 12.00 \\
3-With damages & $88 \mathrm{~B}$ & $87 \mathrm{~B}$ & $98 \mathrm{~B}$ & 12.09 & $90 \mathrm{~B}$ & $92 \mathrm{~B}$ & 12.47 \\
\hdashline CV\% & 2.38 & 2.47 & 0.58 & 2.43 & 3.76 & 1.46 & 3.88 \\
\hline
\end{tabular}

Note. Means followed by the same letter in the column do not differ by the Scott-Knott test at 5\% probability.

These results show that the presence of damages in seeds affect their physiological potential. How can be observed, there was decrease in the percentage of germination and vigor by the tests of FC, E, ESI, CT and AA in the lot with damages in seeds.

The effect of damages is more evident when seeds are submitted to accelerated aging. In general, the quality reduction can be related to the deterioration process and the seedling bad formation to the damage next to the embryo axel (Gomes Júnior \& Cícero, 2012). According Marchi et al. (2006) the physiological potential and the incidence of fungi are negatively influenced with the increase of proportion of damages in seeds.

Similar result was found by Oliveira et al. (1997), working with effect of harvest method on physical, physiological and sanitary quality of maize seeds. According these authors, seeds mechanically harvested presented 18 percentual points more of mechanical damages than those seeds manually harvested, what can justify the inferior results found in the germination test, cold test, accelerated aging test, emergence speed index and stand at 15 days for these seeds.

By the EC test was not possible to separate the lots according the physiological quality. This test is based in the membrane integrity system, being one of the first signals of deterioration. This attribute was not determinant for the reduction of the physiological potential of seeds. This result in contrary to that found by Ribeiro et al. (2009), where the authors verified increase of the electric conductivity values when the presence of mechanical damages, being possible the separation of lots in different levels of vigor.

The non-significance of EC can be explained by the fact of seeds with damage presents mostly, only intern damages (latent damages), what was proved by the visual analyze realized in lots (Table 1).

By tetrazolium test (Table 3) was also possible the identification of damages and the separation of lots in three levels of quality, being the lot 2 with higher quality followed by the lot 1 . The lot 3 was the worst lot, presenting high number of damages and inviable seeds.

Table 3. Percentage of viable seeds with damages (VCD), viable without damages (VWD) and inviable (IN) obtained by tetrazolium test (TZ)

\begin{tabular}{llll}
\hline Lots & VCD & VWD & IN \\
\hline 1-Original & $31 \mathrm{~B}$ & $66 \mathrm{~B}$ & $11 \mathrm{~B}$ \\
2-Without damages & $20 \mathrm{~A}$ & $75 \mathrm{~A}$ & $6 \mathrm{~A}$ \\
3-With damages & $33 \mathrm{~B}$ & $53 \mathrm{C}$ & $16 \mathrm{C}$ \\
\hline CV $(\%)$ & 13.57 & 7.51 & 17.12
\end{tabular}

Note. Means followed by the same letter in the column do not differ by the Scott-Knott test at 5\% probability.

The sanity test (Blotter Test) identified five different genders of fungi; Drechsrela sp., Fusarium sp., Nigrospora sp., Penicillium sp. and Trichoderma sp. The genders Drechsrela sp., Fusarium sp. and Penicillium sp. were found in both lots, being Fusarium in higher quantity mainly in lot 3, which presented higher number of contaminated seeds. 
Studying about the relation between the mechanical damages, the presence of microorganisms and the physiological performance, Cícero and Silva (2003) reported that the injuries in maize seeds, particularly when Aspergillus sp. and Fusarium moniliforme are present, promote a progressive injury mainly when this damage approaches from the embryo.

To the enzymatic systems, superoxide dismutase (SOD), catalase (CAT), malate dehydrogenase (MDH) and alcohol dehydrogenase (ADH), it can be observed that there was no difference in the activity of these enzymes between the lots (Figure 2).

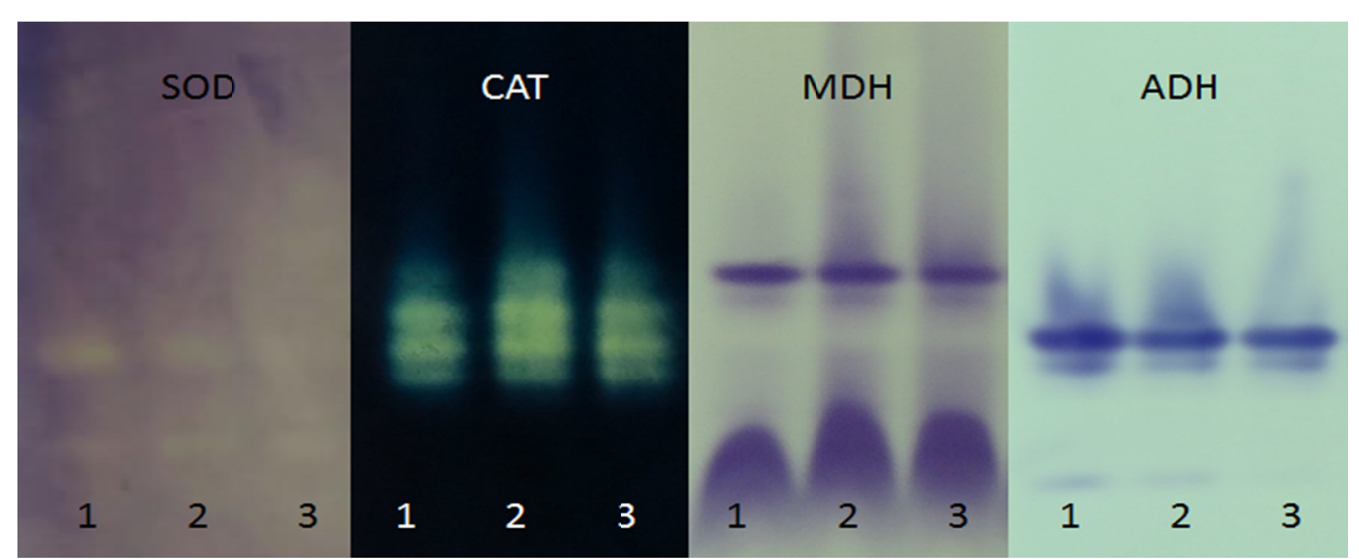

Figure 2. Electrophoretic pattern of enzymes SOD, CAT, MDH and ADH, of three lots of maize seeds

This was an expect result, once the material was freshly harvested and it was not submitted to any kind of stress capable to generate a higher deterioration of these seeds, like chemical treatment and the storage, despite of the damages found.

In the second part of work, after the chemical treatment, seeds were evaluated again according the viability and vigor.

Through the germination test was possible to visualize variation only between lots, which were grouped in two levels, being the lot 1 and 2 similar and superiors to lot 3 .

In present work, seeds were stored by 90 days, which proved to be insufficient to affect the germination of seeds. Similar results were found by Timóteo and Marcos Filho (2013) where the authors reported that seeds from three different hybrids of maize treated with fungicide and insecticide, presented reduction in the germination from 9 months of storage and depending of the genotype, this reduction can be visualized only 15 months after storage. In the other hand, Matos et al. (2013), reported that maize seeds treated with different formulations of fungicide presented increase in the percentage of germination when compared to the control, no treated.

However, this period of storage was sufficient to reduce the vigor of seeds, independently of the lot, how can be observed in the results of first count of germination (FC) (Table 4). There was significant difference for lots, storage and the interaction lots $\times$ storage. According the results of FC, the lots 1 and 3 are similar and inferiors to lot 2. This fact can be related to the presence of latent damages in seeds from this lot. However, the period influenced the vigor represented here, by the first count, culminating in decreasing of percentage of normal seedlings at 90 days to lots 1 and 3 . 
Table 4. Percentage of normal seedlings of first count of germination test of maize seeds after the chemical treatment and storage for 90 days

\begin{tabular}{llc}
\hline \multirow{2}{*}{ Lots } & \multicolumn{2}{c}{ Storage (days) } \\
\cline { 2 - 3 } & $\mathbf{0}$ & $\mathbf{9 0}$ \\
\hline 1-Original & $99 \mathrm{Aa}$ & $85 \mathrm{Bb}$ \\
2-Without damages & $100 \mathrm{Aa}$ & $93 \mathrm{Ab}$ \\
3-With damages & $98 \mathrm{Aa}$ & $84 \mathrm{Bb}$ \\
CV $(\%)$ & 3.70 & \\
\hline
\end{tabular}

Note. Means followed by the same uppercase in the column and lowercase in the line, do not differ by the Scott-Knott test at 5\% probability.

In seedlings emergence test, there were differences only for storage, being the percentage of emerged seedlings inferior after 90 days, independently of lot and chemical treatment, what means, that the chemical treatment and the different lots did not influence the emergence. According to the emergence speed index (ESI) was possible to observe differences for lots, storage and for interaction between lot x storage (Table 5).

Table 5. Emergence speed index (ESI) of three lots of seeds at 0 and 90 days after the chemical treatment of seeds

\begin{tabular}{llc}
\hline \multirow{2}{*}{ Lots } & \multicolumn{2}{c}{ Storage (days) } \\
\cline { 2 - 3 } & $\mathbf{0}$ & $\mathbf{9 0}$ \\
\hline 1-Original & $10.04 \mathrm{Bb}$ & $11.67 \mathrm{Ba}$ \\
2-Without damages & $10.66 \mathrm{Ab}$ & $11.98 \mathrm{Aa}$ \\
3-With damages & $10.62 \mathrm{Ab}$ & $11.53 \mathrm{Ba}$ \\
\hline CV(\%) & 2.91 & \\
\hline
\end{tabular}

Note. Means followed by the same uppercase in the column and lowercase in the line, do not differ by the Scott-Knott test at 5\% probability.

Before the storage, the values for lots 2 and 3 were similar and superior to the value found to lot 1 , however at 90 days, lots 1 and 3 showed inferiors to lot 2. The damages found in seeds from lot 1 , as well as in lot 2 , could have evolved during the period of storage and in this way, contributing to higher deterioration of seeds, resulting in lower initial speed of germination of these lots of seeds in the period evaluated.

According Gomes Júnior et al. (2009), the loss of integrity of cellular membranes is related to the loss of vigor, as well as the mechanical damages, causing the delay of germination. Related to the storage, in all lots, the values of ESI were higher at 90 days, probably due to the fact of the chemical treatment have reduced the incidence of field pathogens on seeds during the storage providing the better initial speed in both lots, what can be confirmed by blotter test.

The results of cold test (CT) were significant only to chemical treatment and the interaction chemical treatment $\mathrm{x}$ storage. At 90 days of storage the chemical treatment positively influenced the percentage of normal seedling when compared to seeds non treated (Table 6).

Table 6. Percentage of normal seedlings obtained by the cold test for control treatment and seeds treated, with 0 and 90 days after the chemical treatment

\begin{tabular}{lll}
\hline \multirow{2}{*}{ Treatment } & \multicolumn{2}{c}{ Storage (days) } \\
\cline { 2 - 3 } & $\mathbf{0}$ & $\mathbf{9 0}$ \\
\hline Non treated (control) & $94 \mathrm{Aa}$ & $93 \mathrm{Ba}$ \\
Chemically treated & $95 \mathrm{Aa}$ & $96 \mathrm{Aa}$ \\
\hdashline $\mathrm{CV}(\%)$ & 1.90 & \\
\hline
\end{tabular}

Note. Means followed by the same uppercase in the column and lowercase in the line, do not differ by the Scott-Knott test at 5\% probability. 
Similar result was found by Von Pinho et al. (1995), where the authors reported that different treatments allowed the higher germination and emergence in comparison to the control no treated in cold test. In other work, Tonin et al. (2014) conclude that vigor is influenced by the hybrid, by the product applied and by the storage condition, and there is reduction in the viability and vigor of hybrid maize seeds treated with thiamethoxan during the period of storage.

By the accelerated aging test (AA) (Table 7), the lots that did not receive chemical treatment were separated in three levels of quality, being the lot 2 with higher percentage of germination, followed by the lot 1 and 3 . When treated, was not observed differences between lots. When was evaluated each lot, it can be noted that only lot 2 was not influenced by treatment. Already, the lots 1 and 3, the values of germination after the AA were superior when seeds were chemically treated. Is possible to observe the positive effect of chemical treatment in seeds even in seeds with higher level of deterioration, being the seeds protected against fungi contamination.

Table 7. Percentage of germination $(\mathrm{G} \%)$ of maize seeds treated and no treated, submitted to the accelerated aging test

\begin{tabular}{lll}
\hline \multirow{2}{*}{ Lots } & \multicolumn{2}{c}{ Treatment } \\
\cline { 2 - 3 } & No treated (control) & Chemically treated \\
\hline 1-Original & $90 \mathrm{Bb}$ & $98 \mathrm{Aa}$ \\
2-Without damages & $96 \mathrm{Aa}$ & $98 \mathrm{Aa}$ \\
3-With damages & $85 \mathrm{Cb}$ & $98 \mathrm{Aa}$ \\
\hline CV $(\%)$ & 5.02 & \\
\hline
\end{tabular}

Note. Means followed by the same uppercase in the column and lowercase in the line, do not differ by the Scott-Knott test at 5\% probability.

In Table 8, it can be observed the influence of chemical treatment as well as the storage in the percentage of germination after the AA test.

Table 8. Germination (G\%) for the accelerated aging test of maize seeds submitted to the chemical treatment and storage

\begin{tabular}{lll}
\hline \multirow{2}{*}{ Storage (days) } & \multicolumn{2}{c}{ Treatment } \\
\cline { 2 - 3 } & No treated (control) & No treated (control) \\
\hline 0 & $97 \mathrm{Aa}$ & $99 \mathrm{Aa}$ \\
90 & $85 \mathrm{Bb}$ & $97 \mathrm{Aa}$ \\
\hline $\mathrm{CV}(\%)$ & 5.02 & \\
\hline
\end{tabular}

Note. Means followed by the same uppercase in the column and lowercase in the line, do not differ by the Scott-Knott test at 5\% probability.

It is noted that before the storage was no influence of the chemical treatment on vigor seeds, with results statically similar to the control and treated seeds in the AA test. However, at 90 days, comparing the seeds no treated with seeds chemically treated, realizes that the first one, obtained inferior percentage of germination, what can be explained by the benefic effect of chemical treatment on stored seeds, fact that can be proved by the results of the sanity test, which showed the efficiency of fungicide in the control of fungi from the gender Fusarium, main field fungi. During the realization of viability and vigor tests after the storage, was verified that seeds were free of storage pests.

For the electric conductivity test, there was significance for lots and the interaction lots $\times$ storage. At 0 days there was no significant difference between lots, and at 90 days, the higher electric conductivity was obtained in lot 3 , being lots 1 and 2 similar (Table 9). 
Table 9. Electric conductivity for each lot of maize seeds during the storage $\left(\mu \mathrm{Scm}^{-1} \mathrm{~g}^{-1}\right)$

\begin{tabular}{llc}
\hline \multirow{2}{*}{ Lots } & \multicolumn{1}{c}{ Storage (days) } \\
\cline { 2 - 3 } & $\mathbf{0}$ & $\mathbf{9 0}$ \\
\hline 1-Original & $10.99 \mathrm{Aa}$ & $10.75 \mathrm{Ba}$ \\
2-Without damages & $11.21 \mathrm{Aa}$ & $10.83 \mathrm{Ba}$ \\
3-With damages & $10.67 \mathrm{Ab}$ & $12.33 \mathrm{Aa}$ \\
\hline CV(\%) & 6.42 & \\
\hline
\end{tabular}

Note. Means followed by the same uppercase in the column and lowercase in the line, do not differ by the Scott-Knott test at $5 \%$ probability.

It can be observed that there was increase in the electric conductivity in lot 3 at 90 days, when compared to other lots in this same period, demonstrating the negative effect of storage and possibly the chemical treatment during storage on damaged seeds. This result is in agreement with the results found by Fessel et al. (2003), where they analyzed the physiological, physical and sanitary quality of maize seeds and verified that the occurrence of mechanical damages promoted the increase in the lixiviation of exudates culminating in higher electric conductivity and consequently reduction of vigor.

The loss of membrane integrity is the first step in seeds deterioration, and on the case of damage seeds, the capacity or the speed of membrane's reorganization seeds is compromised, and in this way, these seeds present higher values of conductivity or higher release of leachates (Fessel et al., 2010).

By the tetrazolium test was possible to observe that for viable seeds with damages, the result was significant only for lots, being the lot 3 with higher number of damage seeds, followed by the lots 1 and 2. For viable seeds without damages, the result of test was significant for both lots and storage. Analyzing the lots, it is noted that the result was inverse to that found for seeds with damages, in this case, the lot 2, presented the higher number of seeds without damages, followed by the lot 1 and 3, which presented high number of damaged seeds. For storage, was possible to observe that the number of seeds without damage increased during the storage, this fact can be related to the reduction of incidence of pathogens during the storage, as well as a possible reduction of the phytotoxic effect of products used in chemical treatment of seeds.

By the analyze of sanity test (Blotter Test) it can be observed higher incidence of Fusarium fungi, which was presented in all lots where the seeds were not chemically treated, independently of the period of storage. Although the incidence of this pathogen was lower at 90 days, the fungi of this gender remained present, result also found by Tanaka (2001), which observed the reduction of this pathogen incidence after the storage, being the cold chamber the local of higher reduction. In this way, was possible to observe the efficiency of chemical treatment in the control of this pathogen and also, the behavior during the storage of seeds.

Many works were developed to verify the effect of Fusarium on maize seeds quality, and according to all these works, the presence of this fungi did not affect the germination of maize seeds (Cappelini et al., 2005; Catão et al., 2013; Moraes et al., 2003), however, it is very important on maize crop, once can cause important diseases like root rot, death of seedlings, ear rot, stalk rot culminating in reductions of productivity and quality (Kuhnem Júnior et al., 2013).

In addition to the genus Fusarium, other gender, even in lower intensities, stand out, as Aspergillus and Penicillium that had an increase in their incidence at 90 days. Both fungi are considered fungi of storage and independently of the chemical treatment, they appeared.

According Borba et al. (2014) the parameters related to deterioration of seeds not always are detected by the viability and vigor tests, being necessary analyzes more sensitive that classifies both seeds from homogeneous lots as well as seeds from heterogeneous lots, as to vigor.

In Figure 3 are presented the electrophoretic patterns of enzymes superoxide dismutase (SOD) and catalase (CAT). SOD is involved in the process of removal of reactive oxygen species (EROs), like superoxide radical $\left(\mathrm{O}_{2}{ }^{-}\right)$, through the dismutation of the radical of superoxide to hydrogen peroxide $\left(\mathrm{H}_{2} \mathrm{O}_{2}\right)$ (Carneiro et al., 2011). It is observed the decrease of the activity of this enzyme at 90 days. Probably the SOD could been consumed with the propose to eliminate the oxidative substances produced during the storage period, independently of the treatment received. In this period the highest activity of the enzyme was in lot 3 of the seeds that received chemical treatment. This fact can be explained by the negative effect of the chemical treatment added to the negative effect of the storage on the damaged seeds. 


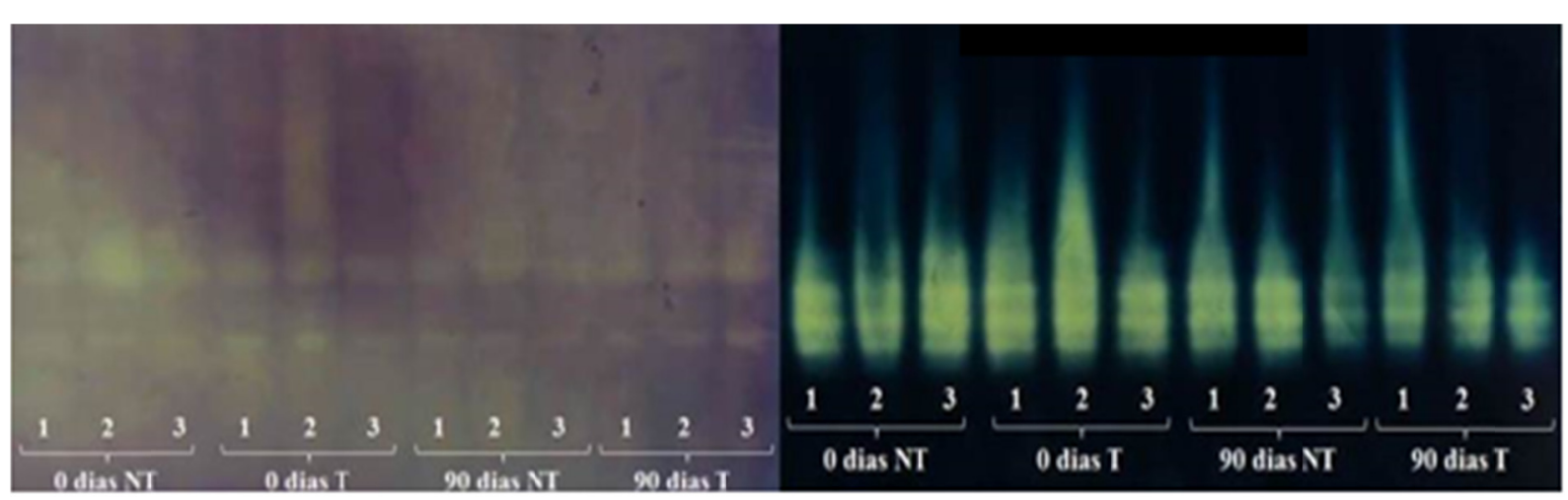

Figure 3. Electrophoretic pattern of enzymes SOD (in the left) and CAT (in the right) of maize seeds before ( 0 days) and at 90 days of storage (NT: no treated; T: chemically treated)

To CAT enzyme, involved in the process of hydrogen peroxide removal, was possible to observe reduction in the activity of this enzyme at 90 days of storage, independently of the treatment received, however, it can be observed higher reduction of CAT activity for seeds treated in this period. Similar result was found to SOD enzyme.

The reduction of the scavenger's enzymes activity, could be related to the losses of seeds viability (Berjak, 2006). Probably the damages found in seeds from lots 1 and 3 could be contributing to the decreasing of these seeds quality. Generally, evaluating the physiological tests, the quality of seeds was not influenced by the storage, however analyzing the results of the first count, emergence of seedling and electric conductivity tests, is possible to observe that the storage contributes to the reduction of vigor, mainly to the lot 3 with damage seeds.

In seeds with greater amount of damages, was observed lower activity of CAT, what can be inferred that these seeds are with low capacity to combat the negative effects of hydrogen peroxide becoming the seeds more sensitive to the effect of free radicals (Timóteo \& Marcos Filho, 2013).

In Figure 4 are presented the electrophoretic patterns of the malate dehydrogenase (MDH) and alcohol dehydrogenase $(\mathrm{ADH})$ enzymes. For $\mathrm{MDH}$ there was no difference in the activity, independently of the treatment or the evaluated period, what means that the respiratory activity was not affected by the chemical treatment and even by the mechanical damages.

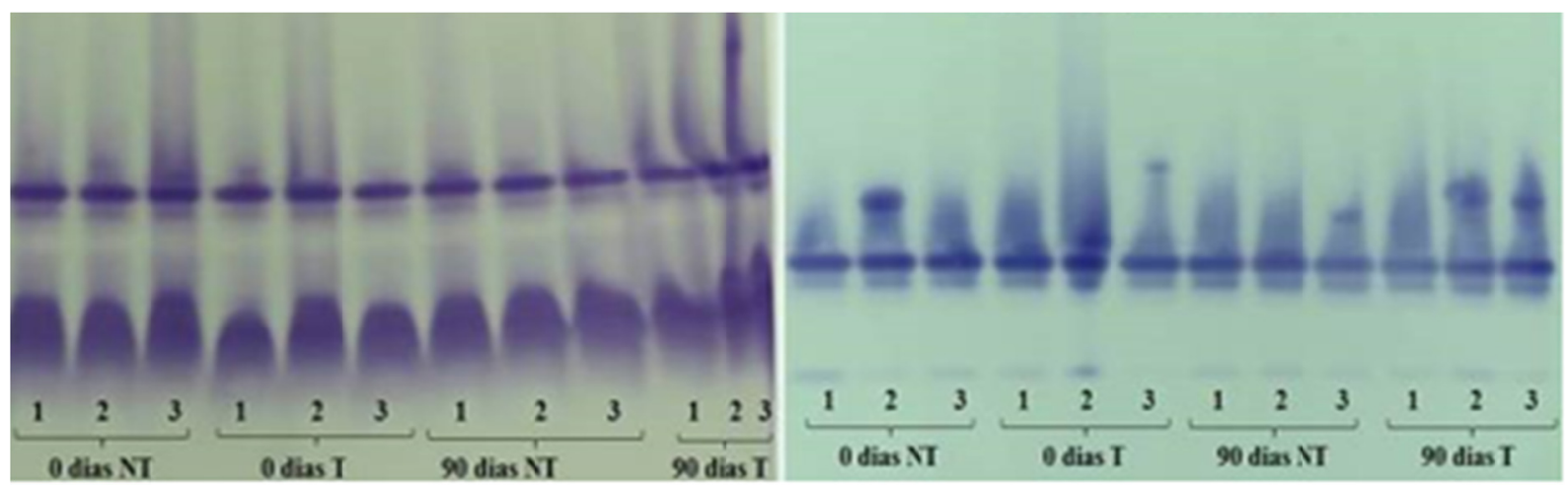

Figure 4. Electrophoretic pattern of enzymes MDH (in the left) and ADH (in the right) of maize seeds before ( 0 days) and at 90 days of storage (NT: no treated, T: chemically treated)

Similar results are found by Brandão Júnior et al. (1999), where they found that the activity of MDH enzyme was less affected by the treatments of aging in maize seeds and also by Spinola et al. (2000) where the authors reported that $\mathrm{MDH}$ kept their enzymatic patterns unchanged with the advance of the deteriorative process.

For the enzyme alcohol dehydrogenase $(\mathrm{ADH})$ it can be verified the reduction of their activity during the storage. However, the seeds chemically treated presented higher activity in comparison with seeds treated only with water, independently of the evaluated period. 
The higher activity of this enzyme at 0 days, for seeds which received chemical treatment, can be related to the stress caused by the application of product and possibility by the storage that takes to the degradation of some product's compound.

Similar result was found by Ferreira et al. (2007), where the authors reported an increase in the activity of ADH in chemical treatment before planting, and reduction of the activity of this enzyme in seeds which were treated six months before planting.

According the physiological datas, as well as the presented zymograms, it can be inferred that the lot 2 (seeds without damages) is the lot of higher quality, mainly due to the results observed in the previous tests which were higher in comparison to the other lots, mainly after the storage by 90 days.

\section{Conclusions}

The chemical treatment is efficient in the pathogens control.

The performance of seeds with external and internal damages can be maintained by 90 days when treated with the fungicide and insecticide and stored in environmental conditions.

The electrophoresis analyzes of enzymes confirms the higher deterioration of seeds no treated during the storage in comparison with the seeds treated.

The mechanical damages found in seeds contributes to the reduction of viability and vigor of maize seeds.

\section{Acknowledgements}

The authors especially thank to CAPES, FAPEMIG and CNPq, for partially supporting this work.

\section{References}

Alfenas, A. C. (2006). Eletroforese e marcadores bioquímicos em plantas e microrganismos (p. 627). Viçosa: UFV.

Berjak, P. (2006). Unifying perspectives of some mechanisms basic to desiccation tolerance across life forms. Seed Science Research, 16(1), 1-15. https://doi.org/10.1079/SSR2005236

Borba, I. C. G. (2014). Metabolismo antioxidativo para separação de lotes de sementes de diferentes graus de homogeneidade. Revista Brasileira de Biociência, 12(1), 20-26.

Brandão Junior, D. S. (1999). Avaliação de danos mecânicos e seus efeitos na qualidade fisiológica de sementes de milho. Revista Brasileira de Sementes, 21(2), 53-58. https://doi.org/10.17801/0101-3122/rbs.v21 $\mathrm{n} 2 \mathrm{p} 53-58$

Brandão Júnior, D. S., Ribeiro, D. C. A., Bernadino-Filho, J. R., \& Vieira, M. G. C. C. (1997). Adequação do teste de condutividade elétrica para determinar a qualidade fisiológica de sementes. Informativo ABRATES, $7(1 / 2), 184$.

Cappelini, L. T. D., Panizzi, R. C., Vieira, R. D., \& Galli, J. A. (2005). Efeito de Fusarium moniliforme na qualidade de sementes de milho. Cientifica, 3(2), 185-191.

Carneiro, M. M. L. C., Deuner, S., Oliveira, P. V., Teixeira, S. B., Sousa, C. P., Bacarin, M. A., \& Moraes, D. M. Atividade antioxidante e viabilidade de sementes de girassol após estresse hídrico e salino. Revista Brasileira de Sementes, 33(4), 752-761. https://doi.org/10.1590/S0101-31222011000400017

Catão, H. C. R. M., Magalhães, H. M., Sales, N. L. P., Brandão Junior, D. S., \& Rocha, F. S. (2013). Incidência e viabilidade de sementes crioulas de milho naturalmente infestadas com fungos em pré e pós-armazenamento. Ciência Rural, 43(5), 764-770. https://doi.org/10.1590/S0103-84782013000500002

Cícero, C. M., \& Silva, W. R. (2003). Danos mecânicos associados a patógenos e desempenho de sementes de milho. Bragantia, 62(2), 305-314. https://doi.org/10.1590/S0006-87052003000200017

Cicero, S. M., \& Banzato Junior, H. L. (2003). Avaliação do relacionamento entre danos mecânicos e vigor, em sementes de milho, por meio da análise de imagens. Revista Brasileira de Sementes, 25(1), 29-36. https://doi.org/10.1590/S0101-31222003000100006

Dias, M. C. L., \& Barros, A. S. R. (1995). Avaliação da qualidade de sementes de milho (p. 41). Londrina: IAPAR.

Fantazzini, T. B., Guimaraes, R. M., Clemente, A. C. S., Carvalho, E. R., \& Machado, J. C. (2016). Fusarium verticillioides inoculum potential and its relation with the physiological stored corn seeds quality. Bioscience Journal, 32(5), 1254-1262. https://doi.org/10.14393/BJ-v32n5a2016-33056 
Ferreira Pinto, T. L., Cicero, S. M., \& Forti, V. A. (2007). Avaliação de danos por umidade, em sementes de soja, utilizando a técnica de análise de imagens. Revista Brasileira de Sementes, 29(3), 31-38. https://doi.org/10. 1590/S0101-31222007000300004

Ferreira, D. F. (2011). Sisvar: um sistema computacional de análise estatística. Ciência e Agrotecnologia, 35(6), 1039-1042. https://doi.org/10.1590/S1413-70542011000600001

Fessel, S. A., Panobianco, M., Souza, C. R., \& Vieira, R. D. (2010). Teste de condutividade elétrica em sementes de soja armazenadas sob diferentes temperaturas. Bragantia, 69(1), 207-214. https://doi.org/10.1590/S000687052010000100026

Fessel, S. A., Sader, R., Paula, R. C., \& Juliana Altafin Galli, J. A. (2003). Avaliação da qualidade física, fisiológica e sanitária de sementes de milho durante o beneficiamento. Revista Brasileira de Sementes, 25(2), 70-76. https://doi.org/10.1590/S0101-31222003000400010

Gomes Junior, F. G., \& Cicero, S. M. (2012). X-Ray analysis assess mechanical demage insweet corn seeds. Revista Brasileira de Sementes, 34(1), 78-85. https://doi.org/10.1590/S0101-31222012000100010

Gomes Junior, F. G., Timóteo, T. S., Kobori, N. N., Pupim, T. L., Gagliardi, B., Carvalho, T. C., ... Cicero, S. M. (2009). Incidência de patógenos e vigor de sementes de milho doce submetidas a danos mecânicos. Summa Phytopathologica, 35(3), 179-183. https://doi.org/10.1590/S0100-54052009000300003

Juliatti, F. C. (2010). Avanços no tratamento químico de sementes. Informativo ABRATES, 20(3), 54-55.

Kuhnem Júnior, P. R., Stumpf, R., \& Del Ponte, E. M. (2013). Características patogênicas de isolados do complexo Fusarium graminearum e de Fusarium verticillioides em sementes e plântulas de milho. Ciência Rural, 43(4), 583-588. https://doi.org/10.1590/S0103-84782013000400004

Maguire, J. D. (1962). Speed of germination: Aid in selection and evaluation for seedling emergence and vigor. Crop Science, 2(2), 176-177. https://doi.org/10.2135/cropsci1962.0011183X000200020033x

MAPA (Ministério da Agricultura, Pecuária e Abastecimento). (2009). Regras para Análise de Sementes (p. 395). Secretaria de Defesa Agropecuária, MAPA, Brasília.

Marchi, J. L., Menten, J. O. M., Moraes, M. H. D., \& Cicero, S. M. (2006). Relação entre danos mecânicos, tratamento fungicida e incidência de patógenos em sementes de milho. Revista Brasileira de Milho e Sorgo, 5(3), 351-358. https://doi.org/10.18512/1980-6477/rbms.v5n3p351-358

Martin, T. N., Tomazella, A. L., Cícero, S. M., Neto, D. D., Favarin, J. L., \& Júnior, P. A. V. (2007). Questões relevantes na produção de sementes de milho - primeira parte. Revista da FZVA, 14(1), 119-138.

Matos, C. S. M., Barrocasi, E. N., Machado, J. C., \& Alves, F. C. (2013). Health and physiological quality of corn seeds treated with fungicides and assessed during storage. Journal of Seed Science, 35(1), 10-16. https://doi.org/10.1590/S2317-15372013000100001

Moraes, M. H. D., Menten, J. O. M., Gravena, J. C., \& Alves, C. A. (2003). Controle químico de Fusarium moniliforme em sementes de milho: Metodologia de avaliação e afeitos sobre a qualidade fisiológica. Fitopatologia Brasileira, 28(6), 626-632. https://doi.org/10.1590/S0100-41582003000600008

Oliveira, J. A., Carvalho, M. L. M., Vieira, M. G. G. C., \& Von Pinho, E. V. R. (1997). Efeito do método de colheita na qualidade física, fisiológica e sanitária de sementes de milho. Revista Brasileira de Sementes, 19(2), 200-206. https://doi.org/10.17801/0101-3122/rbs.v19n2p200-206

Ribeiro, D. M. (2009). Teste de condutividade elétrica para avaliar o vigor de sementes em milho-pipoca (Zea mays L.). Revista Ceres, 56(6), 772-776.

Smiderle, O. J., Gianluppi, D., \& Mourão Júnior, M. (2003). Tratamento e qualidade de sementes de milho durante o armazenamento em Roraima. Revista Acadêmica: Ciências Agrárias e Ambientais, 1(4), $75-83$. https://doi.org/10.7213/cienciaanimal.v1i4.14988

Spinola, M. C. M., Cícero, S. M., \& Melo, M. (2000). Alterações bioquímicas e fisiológicas em sementes de milho causadas pelo envelhecimento acelerado. Scientia Agrícola, 57(2), 263-270. https://doi.org/10.1590/S 0103-90162000000200011

Tanaka, M. A. S. (2001). Sobrevivência de Fusarium monliforme em sementes de milho mantidas em duas condições de armazenamento. Fitopatologia Brasileira, 26, 60-64. https://doi.org/10.1590/S0100-41582 001000100010 
Teixeira, M. M. (2002). Avaliação dos danos mecânicos em sementes de milho, durante a movimentação utilizando transportador helicoidal. Revista Ciências Técnicas Agropecuárias, 11(2).

Timóteo, T. S., \& Marcos Filho, J. (2013). Seed performance of diferente corn genotypes during storage. Journal of Seed Science, 35(2), 207-215. https://doi.org/10.1590/S2317-15372013000200010

Timóteo, T. S., \& Marcos Filho, J. (2013). Seed performance of diferente corn genotypes during storage. Journal of Seed Science, 35(2), 207-215.

Tonin, R. F. B., Lucca Filho, O. A., Labbe, L. M. B., \& Rossetto, M. (2014). Potencial físiológico de sementes de milho híbrido tratadas com inseticidas e armazenadas em duas condições de ambiente. Scientia Agropecuária, 5, 7-16.

Vaz Mondo, V. H., \& Cícero, S. M. (2005). Análise de imagens na avaliação da qualidade de sementes de milho localizadas em diferentes posições na espiga. Revista Brasileira de Sementes, 27(1), 9-18. https://doi.org/ 10.1590/S0101-31222005000100002

Vieira, R. D., \& Krzyzanowski, C. F. (1999). Teste de condutividade elétrica. In C. F. Krzyzanowski, R. D. Vieira, \& J. B. França Neto (Eds.), Vigor de sementes: conceitos e testes (pp. 1-26). ABRATES.

Von Pinho, E. V. R. (1995). Efeito do tratamento químico com fungicida sobre a qualidade sanitária e fisiológica de sementes de milho (Zea mays L.). Revista Brasileira de Sementes, 17(1), 23-28. https://doi.org/10.17801/ 0101-3122/rbs.v17n1p23-28

\section{Copyrights}

Copyright for this article is retained by the author(s), with first publication rights granted to the journal.

This is an open-access article distributed under the terms and conditions of the Creative Commons Attribution license (http://creativecommons.org/licenses/by/4.0/). 